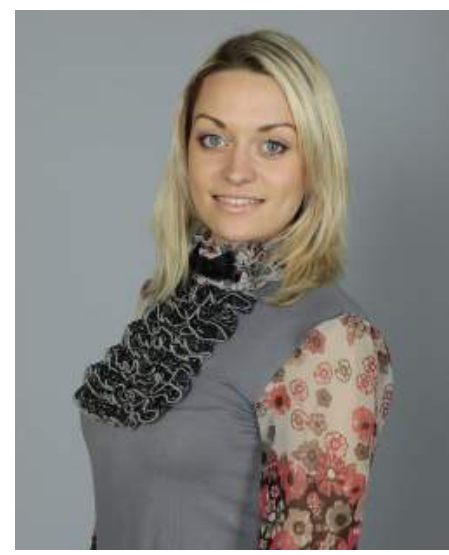

\author{
Олександра Свйонтик, \\ аспірант, \\ Дрогобицький державний педагогічний університет \\ імені Івана Франка \\ (м. Дрогобич)
}

Alexandra Sviontyk,
Postgraduate Student,
Drohobych State Pedagogical University
named after Ivan Franko
(Drohobych)
nadijadydnuk@gmail.com

\title{
АНАЛІЗ ТЕКСТІВ ШКІЛЬНИХ ПІДРУЧНИКІВ ДЛЯ МОЛОДШИХ ШКОЛЯРІВ (90-ТІ РP. ХХ СТ.) ЩОДО ФОРМУВАННЯ ПОЧУТТЯ ВІДПОВІДАЛЬНОСТІ
}

\author{
ANALYSIS OF TEXTS OF SCHOOL TEXTBOOKS \\ FOR YOUNG PUPILS (1990'S) ON THE FORMATION \\ OF THE SENSE OF RESPONSIBILITY
}

В статті висвітлено проблему становлення та розвитку змістового наповнення шкільних підручників з читання для дітей молодшого шкільного віку кінця XX ст., коли постала проблема оновлення підходів до основних виховних та пізнавальних впливів навчальної книги.

Автор статті дає критичну оцінку суспільним та політичним суперечностям, які призвели до необхідності оновлення змісту навчальних книг в освітніх закладах. Приділяє увагу школі першого ступеня як основної у виробленні стратегії подальшої освіти дітей, формуванню у них почуття громадянської відповідальності за допомогою текстів навчальних підручників, спонукання до активного мислення та діяльності на благо свого народу, виховання відповідального ставлення до власного життя, розуміння вагомості своїх освітніх обов'язків під час шкільного навчання.

Метою статті є окреслення переваг та недоліків навчальних книг з читання для дітей молодшого шкільного віку, що формують почуття відповідальності в інтегрованому змісті і пройшли практичну апробацію в навчально-виховних закладах України означеного періоду.

Висвітлено зміст, методичні та мовознавчі особливості підручників українських авторів. Звернено увагу на формування почуття відповідального ставлення дітей до мови, культури, традицій рідного народу. Також в аналізі текстів приділено увагу розвивальним вправам, мовознавчій проблематиці, використанню творів морального спрямування.

Ключові слова: шкільний підручник, зміст підручника, інтеграція, навчальні тексти.

The article deals with the problem of the formation and development of content filling of school textbooks for reading children of junior school age at the end of the twentieth century, when the problem of updating approaches to the main educational and cognitive influences of the study book was raised.

The author of the article gives a critical assessment of the social and political controversies that led to the need to update the content of educational books at the educational institutions. Pays heed to the school of first degree as the main one in preparing the strategy of the further education of children, forming their sense of civic responsibility with the help of texts of educational textbooks, an incentive for active thinking and activities for the benefit of their people, the development of a responsible attitude towards their own lives, an understanding of the importance of their educational duties during the schooling.

The purpose of the article is to outline the advantages and disadvantages of reading books for junior schoolchildren which form a sense of responsibility in the integrated content and have passed practical approbation in educational institutions of Ukraine of the specified period.

It's ascertained the content of textbooks of Ukrainian authors, their methodical and linguistic features. The attention is drawn to the formation of a sense of responsible attitude of children to their native language, culture, development of traditions of the native people. Also in the analysis of texts is paid attention to the importance of developing exercises, linguistic problems, and the use of works of moral direction.

Keywords: School textbook, textbook content, integration, textbooks.

В статье освещена проблема становления и развития содержательного наполнения школьных учебников по чтению для детей младшего школьного возраста конца XX в., Когда появилась проблема обновления подходов к основным воспитательных и познавательных воздействий учебной книги.

Автор статьи дает критическую оценку общественным и политическим противоречиям, которые привели к необходимости обновления содержания учебных книг в образовательных учреждениях. Уделяет внимание школе первой ступени как основной в выработке стратегии дальнейшего образования детей, формированию у них чувства 
гражданской ответственности с помощью текстов учебников, побуждение к активному мышлению и деятельности на благо своего народа, воспитание ответственного отношения к собственной жизни, понимание значимости своих образовательных обязанности " связей во время школьного обучения.

Целью статьи является определение преимуществ и недостатков учебных книг по чтению для детей младшего школьного возраста, формируют чувство ответственности в интегрированном содержании и прошли практическую апробацию в учебно-воспитательных заведениях Украины указанного периода.

Освещены содержание, методические и языковедческие особенности учебников украинских авторов. Обращено внимание на формирование чувства ответственного отношения детей к языку, культуре, традициям родного народа. Также в анализе текстов уделено внимание развивающим упражнениям, языковедческой проблематике, использованию произведений нравственного направления.

Ключевые слова: школьный учебник, содержание учебника, интеграция, учебные тексты.

Постановка проблеми в загальному вигляді та її зв'язок з важливими науковими та практичними завданнями. Ідея інтернаціональної моделі школи, яка функціонувала у СРСР в період 70-80-их років в умовах тоталітаризму, не виправдала себе. Адже культивування національного нігілізму, зневажливе ставлення до народних традицій і звичаїв, нехтування загальнолюдськими цінностями, акцентування уваги на класовій боротьбі - все це згубно відбивалося на формуванні духовності дітей, підривало основи народної етики і моралі щодо формування особистісного відповідального ставлення до долі країни. Поряд з такими політичними тенденціями педагоги-новатори у 80-х роках вперше за всю історію радянської педагогіки створили оригінальні підручники для початкової школи з усіх предметів, у тому числі й підручники з читання. Новація ґрунтувалася на використанні народних елементів виховання, втіленні у практику традицій, що сприяють успішному формуванню свідомості дитини-майбутнього громадянина, який виховується на почуттях відповідального ставлення до життя своєї країни.

3 другої половини 80-х років, після багатьох десятиліть манкуртизму, школа в Україні повертається до своїх національних витоків. Підручники нового покоління, складені як за чинними, так і за авторськими програмами, відрізняються від традиційних національною спрямованістю змісту навчального матеріалу, методичним апаратом, системою вправ і завдань, які активізують творчі здібності, формують активну життєву позицію школярів.

Аналіз останніх досліджень і публікацій, у яких започатковано розв'язання проблеми. До проблем відновлення української літератури у навчально-методичних працях на початку 90-их років долучилися відомі вітчизняні та зарубіжні україністи: Г. Грабович, Я. Дашкевич, І. Дзюба, О. Забужко, О. Зуєвський, Л. Костенко, Г. Кочур, В. Мороз, С. Павличко, О. Пахльовська, О. Пріцак, Л. Рудницький, М. Рябчук, В. Скуратівський, О. Черненко та ін.

Аналізом читанок кінця XX ст. займалися бібліографи Т.П.Павлуша, В.О. Ільганаєва, Н.М. Кушнаренко, А.А. Соляник, В.М. Шейко, педагоги О.Сухомлинська, Н.Кузьменко, Б.Іваницька, В.Науменко, Н.БогданецьБілоскаленко, Т.Бугайко, Л.Воєводська, О.Дем'янчук, І.Зязюн, О.Ковальова, Н.Побірченко, методисти О.Савченко, О.Ісаєнко, В.Науменко, М.Захарійчук, Ж.Юзвак, М.Вашуленко, Г.Кирпа, Д.Чередниченко Б.Мельничук, М.Ониськів, Д.Луцик та ін. Питаннями структури змісту шкільних підручників займалися О.Бандура, В.Беспалько, Д.Зуєв, В.Давидов, Л.Долбаєв, Н.Скрипченко А.Сохор, Д.Чередниченко, Н.Чорна; питаннями ролі та місця підручника у навчальному процесі Ю.Бабанський, Є.Пасічник, Д.Луцик. У дослідженнях Т.Лубенця, Б.Саженюк, М.Саженюк, М.Винника, В.Кирилюка, З.Сергійчук, Г.Сагач, Н.Кузьменко переконливо доведено необхідність використання традицій активного особистісного виховання засобами навчальних підручників.

Проте цілісної оцінки особливостей навчально-виховного впливу читанок, які з'явилися на початку становлення сучасної незалежної України, на формування відповідального ставлення до мови, культури і активної громадянської позиції в педагогічній літературі немає.

Формування мети статті. Мета статті - окреслити переваги та недоліки навчальних книг з читання для дітей молодшого шкільного віку, що формують почуття відповідальності у інтегрованому змісті і пройшли практичну апробацію в навчально-виховних закладах України означеного періоду.

Виклад основного матеріалу дослідження з повним обґрунтуванням отриманих наукових результатів. У 1993 році була прийнята Державна національна програма відродження освіти «Україна XXI ст.: стратегія освіти», яка визначила основні напрями реформування змісту шкільної освіти в Україні наприкінці XX ст. Під час реформування освіти у напрямі формування національної ідентичності впродовж 1992 - 1994 рр. побачили світ нові підручники з читання для молодших школярів, зокрема «Материнка» Д.Чередниченка, «Буквар» М.Чорної, Д.Грабаря, «Читанка» Н.Скрипченко, О.Савченко, «Ластівка», «Біла хата», «Писанка» О.Верес (псевдонім Г.Кирпи та Д.Чередниченка). Це альтернативні підручники з читання, створені на основі нових освітніх концепцій національного виховання.

Актуальні проблеми структури шкільного підручника, його змістового та виховного компоненту неодноразово привертали до себе увагу педагогів, методистів, психологів і вчителів-практиків. Проте одностайності у поданні змісту творів досягнуто не було.

Одні автори під структурою навчальної книги для дітей розуміли лише побудову ї̈ предметного змісту і, роблячи акцент на тематиці, як компоненти підручника виділяли розділи і параграфи, які несуть цільове змістове навантаження (О.Бандура, Н.Волошин, О.Савченко). Інші трактують структуру підручника як вираження книжковими засобами способів подачі навчально-виховного матеріалу і, відповідно, компонентами підручника 
вважають текст як змістову одиницю, розвивальні запитання, ілюстрації тощо (М.Вашуленко, В.Мартиненко, С.Жовнір-Коструба, О.Жовнір).

Хочемо проаналізувати позицію методиста В.С. Цетліна, який розглядає структуру підручника для молодших школярів через внутрішню і зовнішню форми презентації змісту: «Внутрішню форму складає система змісту і спрямування процесу навчання, а мовознавчі засоби і зображення в їх поліграфічному оформленні складають зовнішню форму» [9, с. 48].

Структура підручника, як вважає дослідник, становить єдність двох вимог у цілісності навчальної книги: тих, котрі презентують поділ змісту навчального предмету за тематикою впродовж навчального року, і тих, що відображають виховний вплив у навчальному процесі, необхідний для засвоєння змісту, зосередженого в цілісностях першого ряду [9, с. 49].

Таким чином, послуговуючись дефініцією В.С.Цетліна і застосувавши ї̈ зміст до проблеми структурування підручників, до цілісностей першого ряду можемо віднести періоди у букварях (підготовчий, букварний, післябукварний), розділи у читанках, теми, а до цілісностей другого ряду - принципи підбору і способи подачі навчально-виховного матеріалу: тексти, завдання, запитання, тематичні ілюстрації тощо.

Підручники з читання на початку 90-их років здебільшого побудовані відповідно до шкільної програми, завданнями якої $€$ закладання фундаменту для повноцінного оволодіння учнями текстовою навчальною інформацією; розвиток пізнавальних і конкретних умінь учнів; сприяння формуванню національної самобутності молодшого школяра, його духовності [4, с. 18].

Шкільні підручники створені за принципами доступності, науковості, викладу матеріалу від простого до складного, від невідомого до відомого, розвитку пізнавального інтересу та виховання ціннісних орієнтацій, зокрема відповідального ставлення до саморозвитку, долі власної країни. Вони написані на основі єдності освітніх, виховних і розвивальних завдань школи з урахуванням досягнень дитячої літератури, народознавства, літературознавства, педагогічної психології і методики навчання в початковій школі. Проте не всі з них відповідають науковому рівню та вимогам шкільної програми [7, с. 18].

Так, зокрема, програмою передбачено вивчення рукописних рядкових і великих букв українського алфавіту 33 малих та 32-х великих (враховано повернення в український алфавіт великої і малої букви «ґ»). Однак процес відновлення літери «ґ» в українському алфавіті відображений, на жаль, навіть не у всіх букварях, не кажучи вже про читанки.

Так, у «Букварі» Н.Ф.Скрипченко, М.С.Вашуленка (К., 1991, 6-е вид., перероблене) про це нічого не сказано. Нема літери «ґ і в підручнику для 2 класу, виданого Н.Ф.Скрипченко та О.Я.Савченко уже в 1993 році. Слова ж з літерою «ґ наявні у тексті «Читанки» неодноразово: «На гвалт позбігалися люди» [9, с. 125.]; «На дереві хатка стоїть, а хазяїн на ганочку сидить» [6, с. 265] та ін.

Незрозумілою є позиція з цього приводу авторів «Читанки 4/3/» Н.Ф. Скрипченко, О.Я. Савченко, Н.Й. Волошиної (К., 1995, 4-е вид.). У переважній більшості випадків вони не реагують на зміни в українському правописі: «А чорні гави та круки усе походжають поважно» [7, с. 20.]; «гава підсіла й образливо ганьбить»; «коли це саме під містом з'явився Гаврило з гринджолятами» (до того ж у тексті дається примітка: «гринджолята - низькі й широкі сани») [7, с. 265]. Однак у тексті казки Лесі Українки «Біда навчить» та в питаннях до твору слово «ґава» двічі написано правильно [7, с. 276].

Наведені вище приклади прорахунків авторів підручників спричинені насамперед нехтуванням досвіду визначних українських педагогів та мовознаців. Відомий український письменник та мовознавець XX століття Б.Антонечко-Давидович писав у статті «Літера, за якою тужать»: «Скасування цієї літери припало на той час, коли вчинено було багато перекручень і збочень, коли з'явились «реформатори» не тільки українського правопису, а й самої української мови...» [1, с. 211].

Отже, учні не отримували відповідної граматично правильно побудованої навчальної книги, де рідна мова відкривається перед ними новими гранями, книги, що сприяє духовному збагаченню учнів, відновленню української культури через відчуття багатства рідної мови.

Шкільною програмою передбачено ознайомлення учнів 2 та 4 класів з творами письменників діаспори про рідну Україну. Оксана Верес (Г.Кирпа, Д.Чередниченко) у підручниках «Ластівка: Читанка для 2 класу» (Київ, 1992) та «Писанка: Читанка для 4 класу» (Київ, 1992) добре представили твори письменників діаспори, імена яких замовчувалися та вилучалися з української культури в часи радянщини. У «Писанці» надруковані «Рідна мова» Івана Багряного, «Осінь» Юрія Клена, «Гіацинт» Оксани Лятуринської, «Човник з голубим вітрилом» Віри Вовк та ін. Проте недостатньо уваги приділено інформації про авторів, їхньому громадянському подвигу. За незначним винятком другокласники, прочитавши «Осінь» Дмитра Чуба, «Рідну хату» Ганни Черінь, «Порошинку» Олекси Веретенченка, «Вітаю зиму» Юрія Клена, можуть отримати коротку інформацію про цих письменників, хоча вона і не має патріотичного змісту. У підручнику для 2 класу «Читанка» (Київ, 1993) та підручнику «Читанка 4/3/ класи» (Київ, 1995) українська діаспора не представлена жодним твором. А добірка літературно якісних та патріотичних за змістом творів є значною.

Істотним недоліком окремих підручників $€$ також недостатньо продуманий відбір інформації, не враховано про цьому її значимість для найменших школярів, критерій новизни, відповідності віковим особливостями учнів, різноманітності у структуруванні матеріалу. Як стверджував відомий психолог Г.С.Костюк, «Вік учнів накладає 
певні обмеження на їхні пізнавальні можливості, які залежать не тільки від попередньо набутих знань, а й від рівня сформованості пізнавальних дій і операцій, зв'язаних з ними психічних властивостей учнів, в також від особливостей працездатності їхнього організму. Учні оволодівають на кожному віковому етапі тим, що не виходить за межі їхніх можливостей, до засвоєння чого вони готові» [3, с. 410].

Інформація сприймається учнями з інтересом тоді, коли містить щось несподіване, цікаве з погляду дитини. Разом з тим нова інформація може значною мірою втратити свою новизну і пізнавальну привабливість, коли подається у підручнику одноманітно, мовою наукового стилю зі значною кількістю термінів і невідомих для дітей певного вікового періоду слів. Зайвий інтелектуалізм, логіко-понятійний підхід ослаблює роботу творчої уяви дитини. Там, де приділяється недостатня увага безпосередньому чуттєвому сприйняттю, виникає своєрідна диспропорція між великою кількістю засвоєної інформації і дуже низьким рівнем естетичних переживань, що не сприяє формуванню у дітей активної життєвої позиції, відповідального особистісного ставлення. «Жодна проповідь, - підкреслював Л.С.Виготський, - так не виховує, як живий біль і живе почуття» [2, с.113].

Отже, без недостатньої активізації емоційних переживань не відбудеться повноцінне спілкування учнів 3 підручником. Виникає «своєрідний гносеологічний бар'єр між характером самої інформації і способами донесення її до свідомості учнів» [3, с.17]. Звичні і добре відомі школярам способи представлення інформації у підручнику (одні і ті ж стереотипні завдання та запитання, нецікаві тексти тощо), способи передачі знань вчителем (стандартна структура уроку, прийоми відтворення прочитаного та авторитарно-імперативні методи впливу на учнів тощо) стають психологічним бар'єром для активізації пізнавальних мотивів навчальної діяльності учнів. Багатократний вплив подібних за своїм характером подразників неминуче викликає процес гальмування уваги у наймолодших учнів і загальмовує їх активний особистісний розвиток.

Початок 90-их років ознаменований виходом кількох читанок народознавчого спрямування, рекомендовані як додаткова навчальна література. Вони гідно представили твори кращих українських письменників і мали національне виховне спрямування, що сприяло формуванню активної громадянської позиції, відповідального ставлення до себе як носія рідної культури. Ці читанки були Серед них читанки «Рости на щастя України-мами» (1991) і «Я дитина українська» (1993), які уклали й відредагували Б.Мельничук і Б.Проник, а також антологія духовної поезії західноукраїнських авторів «Богославень» (1994), редактори-упорядники яких Б.Мельничук, М.Ониськів.

Розглянемо «Читанку» для молодших класів авторки О.Стешенко, яку перевидали як одну 3 кращих у 1991 р. У підручнику вміщені перлини усної народної поетичної творчості, зразки художнього спадку Т.Шевченка, П.Куліша, М.Старицького, С.Руданського, Л.Глібова, І.Франка, Лесі Українки, М.Коцюбинського, Б.Грінченка, О.Олеся, В.Винниченка та інших класиків української літератури, причому твори упорядник добирала 3 урахуванням вікових особливостей учнів, відповідно до їх розвитку й зацікавленостей. Читанка відкривається поетичними рядками Т.Шевченка, присвяченими матері: «У нашім раї, на землі Нічого кращого немає, Як тая мати молодая з своїм дитяточком малим...», що ознаменовує відповідальне та шанобливе ставлення до Матері як основи життя на землі.

Одразу ж за поезією вміщено українські народні приказки: «Своя дитина кожній мамі найкраща»; «Рад би до дітей небо прихилити та зорями вкрити»; «як мати рідненька, то й сорочка біленька». Далі подаються оповідання про матір «Мій подарунок» Л.Старицької-Черняхівської, вірші Я.Щоголіва, О.Олеся, оповідання М.Рильського, байка Л.Боровиковського, українська народна пісня. Не надаючи читанці енциклопедичного характеру, О.Стешенко, однак, згрупувала твори таким чином, щоб їх зміст розширював уявлення дітей про природу та навколишній світ, про «менших наших братів» - птахів та звірів; виховував у школярів любов до людей взагалі, до товаришів, до рідного краю, спонукав їх до проявів почуття відповідальності за природу.

За художніми текстами про матір розташовані оповідання, приказки, поезії, байки, народні пісні про дружбу, про природу. Виразно простежується тема сирітства (вірш Т.Шевченка «Сирітка», приказки: «За сиротою Бог з калитою»; «Чужа ласка - сироті Великдень»; «На сирітський жаль ніхто не вважає» тощо), що є моральним важелем виховання співчуття, милосердя.

О.Стешенко добирала твори за тематичним принципом. Тексти були представлені з урахуванням ступеня зображувальних прийомів, що мають безпосередній емоційно-образний вплив на дитину, на характер і глибину сприйняття нею тексту. Вміщені у підручнику твори охоплювали всі жанри літературної творчості: вірші, оповідання, казки, байки, пісні, приказки, що відображає багатство української мови.

Надаючи великого значення рідній літературі в духовному розвитку особистості дитини, О.Стешенко подає твори для дітей і зарубіжних авторів, зокрема казки та оповідання Г.-К.Андерсена, Д.Кіплінга, Ед.Амічіса у перекладах М.Старицького, Ю.Сірого, О.Діхтяря, що сприяють формуванню у дітей почуття відповідального ставлення до близьких людей, природи, підкреслють значимість високоморальних вчинків. Водночас твори, вміщені у книзі, формують культурологічне сприйняття творів, ознайомлюють із зарубіжними і вітчизняними авторами, сприяють розвиткові вмінню зіставляти зміст, виокремлювати проблематику текстів.

Проблема адекватного відтворення оригіналу стала актуальною особливо в 90-ті роки. У переважній більшості тогочасних підручників ім'я перекладача не зазначалося. На жаль, це давало можливість друкувати в навчальній літературі для дітей переклади сумнівної якості на зразок тих, які подаються в підручнику для 2 класу 
«Читанка» (К., 1993), як-от російська колоскова «Матінка й діточки»: «Діточки рядком сидять I на матінку глядять. Баю-бай! Баю-бай! I на матінку глядять».

Хочемо виділити підручники Оксани Верес (Г.Кирпи, Д.Чередниченка) «Ластівка» (К., 1992), «Біла хата» (К., 1992) та «Писанка» (К., 1992). Їх автори чи не вперше у пострадянський період звернули увагу на лінгвістичний аспект відтворюваних перекладачами текстів зарубіжних письменників.

Повертаючись до принципів відбору, структурування та способів пред'явлення навчального матеріалу в підручнику «Рідні колоски», необхідно підкреслити, що О.Стешенко не відокремлювала (графічно чи назвою) тематичні розділи. Матеріал читанки згруповано за своєрідними емоційно-пізнавальними колами, метою яких $€$ спонукання дитини до моральних роздумів: художні тексти, що збуджують симпатії до людини, звірів, рослин, відображають народний побут, традиції, звичаї, культуру, історію, описують взаємини, які сприяють виробленню відповідального ставлення до культури свого народу, спонукають до моральних проявів у стосунках між людьми.

Упорядник читанки «свідомо усунула колишні шаблонні рубрики, що наче здушували весь художній матеріал в кам'яних формах відомої тенденційності; укладався матеріал з метою подачі художніх зразків, починаючи від найпростіших, найзрозуміліших дітям, зростали помалу до зразків більш складного змісту, глибших психологічних переживань героїв і ширших питань, які порушує той або інший твір» [8, с. 3].

Окрім того, читанка ілюстрована репродукціями з малюнків Т.Шевченка, які вдало доповнюють навчальний матеріал. Зміст підручника не втратив своєї актуальності, оскільки при доборі інформації та матеріалу упорядник керувалася не класовими пріоритетами, а загальнолюдськими цінностями та художньо-естетичними якостями пропонованих творів. Уміщені у підручнику художні тексти допомагали дитині усвідомити (звісно, з допомогою вчителя через спеціальну роботу над змістом і формою), що перед нею не просто цікава і пізнавальна інформація, а витвір словесного мистецтва. Вдало підібрані зразки літературної класики з урахуванням вікових особливостей та пізнавальних потреб молодших школярів відкривали перед ними багатства довкілля і людських стосунків, викликали почуття відповідального ставлення до культурної спадщини рідного народу, відповідальності у людських взаєминах, піклування про природу, спонукали до вироблення оцінних суджень, власного ставлення до дійсності. Така книга за умови сучасного художньо-технічного оформлення та поліграфічного забезпечення може зайняти гідне місце серед інших виховних підручників.

В умовах тоталітаризму найважливішими критеріями, за якими добиралися в підручниках тексти для читання, були класовість та комуністична партійність. Твори з яскраво вираженою національною своєрідністю замовчувалися або піддавалися перекрученню. Букварі й читанки були проникнуті заполітизованими настановами, творами про «щасливе дитинство», організоване партією. Автори застосовували репродуктивні форми опрацювання художнього і пізнавального текстів. На противагу цим навчальним книгам, читанка «Рідні колоски» О.Сташенко є гідною альтернативою у процесі виховання в учнів почуття моральної відповідальності, а також формування у них пізнавальної активності.

Перегляд підручників з читання для початкової школи, виданих упродовж радянського періоду, засвідчує, що головними джерелами текстів у цих навчальних книгах були не усна народна творчість у її розмаїтті жанрів, не твори художньої класичної та сучасної української і зарубіжної літератури, а низькопробна кон'юнктурна продукція часто маловідомих літераторів.

Переважна більшість підручників 90-х років містять тексти, які розкривають найкращі риси українського народу, любов дорослих і дітей до України і рідної мови. Вони доносять до читача красу природи України, ставлення самої людини до неї, вчать бути особливими спостерігачами, помічати в житті природи та людини багато спільного, а також знайомлять з далеким минулим, складною історією рідного краю, нашої держави, волелюбним, щедрим і талановитим народом.

Добираючи тексти для підручників, автори читанок керувалися в основному тематичним принципом розміщення художнього й відповідного йому дидактичного матеріалу. Цей принцип передбачає розташування творів за розділами з метою забезпечення логічних і тематичних зв'язків між творами із врахуванням їх поступового ускладнення.

Аналізуючи підручники, ми помітили, що розпочинаються вони по-різному: у більшості з них одразу ж 3 першої сторінки починається виклад навчального матеріалу; в інших спочатку подається «Слово до української дитини», як-от у підручниках Оксани Верес (Г.Кирпи, Д.Чередниченка) «Ластівка», «Біла хата» та «Писанка». Форми особистісного звертання спонукають дитину до роздумів над значимістю кожної людини у процесі побудови власної держави, спонукають бути відповідальними перед суспільством, бути гідним нащадками славних предків.

Для підручників з читання такі вступні звернення до школярів є необхідними, оскільки вони створюють певне психологічне налаштування, що допомагає підготувати учнів до кращого сприйняття специфічного навчального матеріалу - художнього слова. Під час опрацювання тексту звертання важливим $є$ не лише те, яку кількість інформації засвоїли учні і які теоретичні узагальнення вони зробили, а який вплив робить одержана інформація на розвиток особистості школяра.

Наприкінці розділів зазвичай розміщені завдання та запитання, які допомагають учневі пригадати найважливіше, узагальнити й упорядкувати засвоєні знання, спонукають до роздумів та викликають бажання 
вчитися, бути корисним суспільству. Окремі підручники подають наприкінці курсу ще й коротенькі підсумкові статті. Цим, зокрема, вирізняється «Буквар» М.Чорної, Д.Грабаря.

Висновки і перспективи подальших досліджень. Проблема створення стабільного підручника з читання у 90-х роках набула державної ваги, а її вирішення залежало від активної співпраці спеціалістів різного профілю: мовознавців, педагогів, психологів, художників тощо. Інтегроване вивчення кількох навчальних предметів чи їх складових ґрунтується на провідній ідеї, що забезпечуватиме цілісність курсу. Такою ідеєю у книгах для читання вважаємо орієнтацію на формування засобами кращих зразків літератури моральної відповідальності дитини у ставленні до культури, природи, суспільства. Позитивними змінами у текстовій частині підручників з читання 90-их років вважаємо наповнення їх творами з національно-культурного спадку нашого народу. Адже, окрім завдання навчити дітей читати, реалізовується виховне завдання - формування відповідального ставлення до долі власного народу, відчуття відповідальності за майбутнє країни тощо. Порівняно з традиційними підручниками, в яких акцент роблять на засвоєнні системи знань, принциповою відмінністю розвивальних підручників 90-их років $є$ те, що вони навчають дітей думати й розуміти, самостійно орієнтуватись у сучасному світі, допомають формувати почуття відповідальності, розвивають творчі здібності, формують особистісні, національні та загальнолюдські цінності.

1. Антонечко-Давидович Б. Як ми говоримо / Б.Антонечко-Давидович. - К.: Слово, 1991. - 268 с.

2. Виготский Л.С. Педагогическая психология / Л.С.Виготский. - М.: Просвещение, 1926. - 113 с.

3. Костюк Г.С. Навчально-виховний процес і психічний розвиток особистості / Г.С.Костюк. - К.: Слово, $1989 .-410$ с.

4. Програми середньої загальноосвітньої школи 1 - 4 / 1-й/ класи. - К., 1994. - С. 18 - 19 (old.mon.gov.ua/ua/activity/ education/56/692/).

5. Пасічник Є. Концепція літературної освіти / Є.Пасічник // Слово і час. - 1993. - № 6. - С. $70-77$.

6. Скрипченко Н.Ф. Буквар для 2-го класу чотириріч. почат. шк. - 6-те вид., перероб. / Надія Федорівна Скрипченко, Микола Самійлович Вашуленко. - К.: Освіта, 1993. - 144 с.

7. Скрипченко Н.Ф. Читанка 4/3 класи для чотириріч. почат. шк. - 4-те вид., перероб. / Н.Ф.Скрипченко, О.Я.Савченко, Н.Й.Волошина. - К.: Освіта, 1995. - 364 с.

8. Стешенко О. Рідні колоски: Читанка для молодших класів гімназій. Частина 1-3. / О.Стешенко. - К.: в-во І.Д.Ситіна, 1917. -242 c.

9. Цетлин В.С. О структуре ученика / В.С.Цетлин // Теоретические проблемы современного школьного учебника. - М.: Просвещение, 1989. - Вип. 5. - С. 42 - 54.

\section{Reference}

1. Antonechko-Davydovych B. Yak my govorymo / B.Antonechko-Davydovych. - K.: Slovo, 1991. - $268 \mathrm{~s}$.

2. Vygotskij L.S. Pedagogicheskaya psikhologiya / L.S.Vygotskij. - M.: Prosveshcheniye, 1926. - $113 \mathrm{~s}$.

3. Kostyuk G.S. Navchal'no-vykhovnyj proces i psykhichnyj rozvytok osobystosti / G.S.Kostyuk. - K.: Slovo, $1989 .-410 \mathrm{~s}$.

4. Programy seredn’oyi zagal'noosvitn`oyi shkoly 1-4 / 1-j/ klasy. - K., 1994. - S. 18 - 19 (old.mon.gov.ua/ua/activity/ education/56/692/).

5. Pasichnyk Ye. Koncepciya literaturnoyi osvity / Ye.Pasichnyk // Slovo i chas. - 1993. - № 6. - S. $70-77$.

6. Skrypchenko N.F. Bukvar dlya 2-go klasu chotyryrich. pochat. shk. - 6-te vyd., pererob. / Nadiya Fedorivna Skrypchenko, Mykola Samijlovych Vashulenko. - K.: Osvita, 1993. - 144 s.

7. Skrypchenko N.F. Chytanka 4/3 klasy dlya chotyryrich. pochat. shk. - 4-te vyd., pererob. / N.F.Skrypchenko, O.Ya.Savchenko, N.J.Voloshyna. - K.: Osvita, 1995. - 364 s.

8. Steshenko O. Ridni kolosky: Chytanka dlya molodshykh klasiv gimnazij. Chastyna 1-3. / O.Steshenko. - K.: v-vo I.D.Sytina, 1917. $-242 \mathrm{~s}$.

9. Cetlin V.S. O strukture uchenika / V.S.Cetlin // Teoreticheskiye problemy sovremennogo shkol'nogo uchebnika. - M.: Prosveshheniye, 1989. - Vyp. 5. - S. 42 - 54.

Рецензент: Чепіль М.М., доктор педагогічних наук, професор Дрогобицького державного педагогічного університету імені Івана Франка

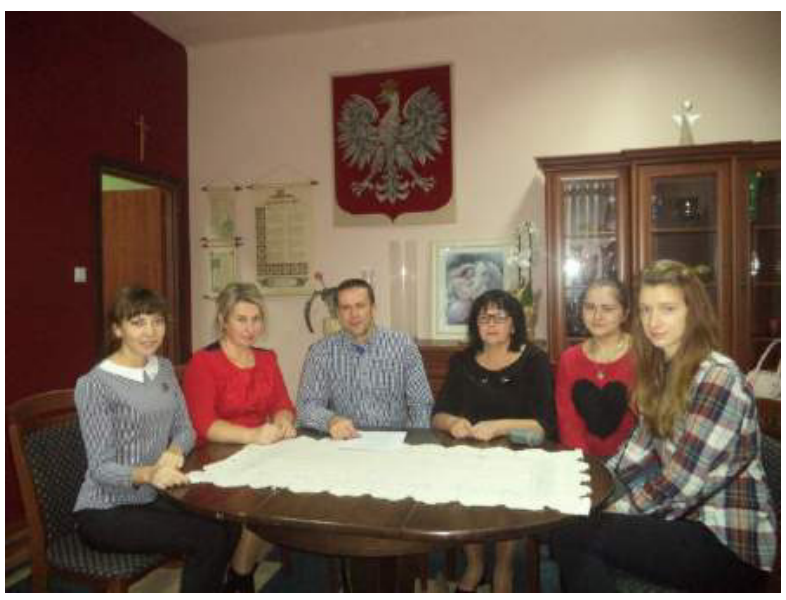

